\title{
Systematic Review \\ Human Co-Infections between Borrelia burgdorferi s.l. and Other Ixodes-Borne Microorganisms: A Systematic Review
}

\author{
Pierre H. Boyer ${ }^{1, *}$, Cédric Lenormand ${ }^{1,2}$, Benoît Jaulhac ${ }^{1,3}$ and Emilie Talagrand-Reboul ${ }^{1}$ \\ 1 Institut de Bactériologie, Fédération de Médecine Translationnelle de Strasbourg, University of Strasbourg, \\ UR7290, ITI InnoVec, 3 Rue Koeberlé, F-67000 Strasbourg, France; cedric.lenormand@chru-strasbourg.fr (C.L.); \\ jaulhac@unistra.fr (B.J.); talagrandreboul@unistra.fr (E.T.-R.) \\ 2 Service de Dermatologie, Clinique Dermatologique, Hôpitaux Universitaires de Strasbourg, \\ F-67000 Strasbourg, France \\ 3 French National Reference Center for Borrelia, Hôpitaux Universitaires de Strasbourg, \\ F-67000 Strasbourg, France \\ * Correspondence: pierreboyer@unistra.fr
}

Citation: Boyer, P.H.; Lenormand, C.; Jaulhac, B.; Talagrand-Reboul, E. Human Co-Infections between Borrelia burgdorferi s.l. and Other Ixodes-Borne Microorganisms: A Systematic Review. Pathogens 2022, 11, 282. https://doi.org/10.3390/ pathogens 11030282

Academic Editor: José A. Oteo

Received: 12 January 2022

Accepted: 19 February 2022

Published: 23 February 2022

Publisher's Note: MDPI stays neutral with regard to jurisdictional claims in published maps and institutional affiliations.

Copyright: (C) 2022 by the authors. Licensee MDPI, Basel, Switzerland. This article is an open access article distributed under the terms and conditions of the Creative Commons Attribution (CC BY) license (https:// creativecommons.org/licenses/by/ $4.0 /)$

\begin{abstract}
When it comes to tick-borne diseases, co-infections are often mentioned. This concept includes several entities. On the one hand, tick vectors or vertebrate reservoir host can harbor several microorganisms that can be pathogenic for humans. On the other hand, human co-infections can also be understood in different ways, ranging from seropositivity without clinical symptoms to co-disease, i.e., the simultaneous clinical expression of infections by two tick-borne microorganisms. The latter, although regularly speculated, is not often reported. Hence, we conducted a systematic review on co-infections between B. burgdorferi s.l., the etiological agent of Lyme borreliosis, and other microorganisms potentially transmitted to humans by Ixodes spp. ticks. A total of 68 relevant articles were included, presenting 655 cases of possible co-infections. Most cases of co-infections corresponded to patients with one tick-borne disease and presenting antibody against another tickborne microorganism. Co-disease was particularly frequent in two situations: patients with clinical symptoms of high fever and erythema migrans (EM), and patients with neurological symptoms linked to the TBEv or a neuroborreliosis. No impact on severity was evidenced. Further studies are needed to better appreciate the frequency and the impact of co-infections between several tickborne microorganisms.
\end{abstract}

Keywords: tick-borne diseases; co-infection; Borrelia burgdorferi s.l.; Anaplasma phagocytophilum; TBEv; Babesia spp.

\section{Introduction}

Lyme borreliosis (LB) is the most frequent vector borne disease in the northern hemisphere, which is caused by bacteria belonging to the Borrelia burgdorferi sensu lato complex [1]. These bacteria are transmitted by a group of closely related tick species designated as Ixodes ricinus complex [2]. These tick species can also transmit several microorganisms, including parasites, such as Babesia spp.; viruses, such as the Tick-Borne Encephalitis (TBE) virus responsible for TBE; and bacteria, such as Anaplasma phagocytophilum, the etiological agent of Human Granulocytic Anaplasmosis (HGA). Vector epidemiology data obtained on field collected ticks by molecular biology, converge and show that ticks can harbor several microorganisms at the same time [3,4], with differences of prevalence according to the life stages of ticks [5]. Moreover, in a given reservoir vertebrate host, the prevalence of co-infections between different microorganisms is more frequent than expected; B. microti, Neoehrlichia mikurensis, and B. burgdorferi s.l. are more frequently associated in rodents $[6,7]$.

However, concerning human co-infection, the situation is more complex. Indeed, the term 'co-infection' mixes several different concepts. 'Co-infection' is more frequently used to refer to multiple seropositivity without an associated disease. Asymptomatic 
seropositivity appreciates tick-borne microorganisms (TBMs) exposure in a given population (e.g., forestry workers and people from an endemic area for tick-borne diseases (TBDs)). In this case, 'co-infection' designates the co-exposure and/or the successive exposure to TBMs without associated symptoms [8] and should take into account the notion of seroprevalence in the general population. This type of study can also be conducted in patients with a given tick-borne disease by detecting antibodies against another TBM, highlighting previous contact with a TBM [9]. In addition, 'co-infection' can also refer to two infections, one being clinically expressed and the other being asymptomatic. For example, in a study on erythema migrans (EM), which proves an active infection of B. burgdorferi s.l., Jahfari et al. [10] used molecular tools to show that $2.7 \%$ of the patients were also co-infected with N. mikurensis, A. phagocytophilum, B. divergens, or B. miyamotoi, without additional symptoms other than those reported for LB. Finally, only a few cases of 'co-disease' have been reported.

The purpose of this literature review was to describe cases of co-infections published so far between B. burgdorferi s.l., the etiological agent of LB, and other Ixodes-borne microorganisms. We attempted to describe cases of co-infection where at least one disease was clinically expressed. Hence, seroprevalence studies without clinical data were excluded.

\section{Results}

\subsection{Study Selection and Search Results}

On 28 July 2021, following the search strategy defined in Section 4.1, a total of 1360 publications were found in the PubMed database, 1246 papers were rejected based on the abstract reading by the two independent reviewers. The screening phase resulted in 114 records selected. Four publications could not be accessed, and 42 more articles were rejected after reviewing the entire article. Figure 1 summarizes the bibliographic search strategy and the reasons for excluding articles. The complete list of publications reviewed is provided in the additional file Table S1.

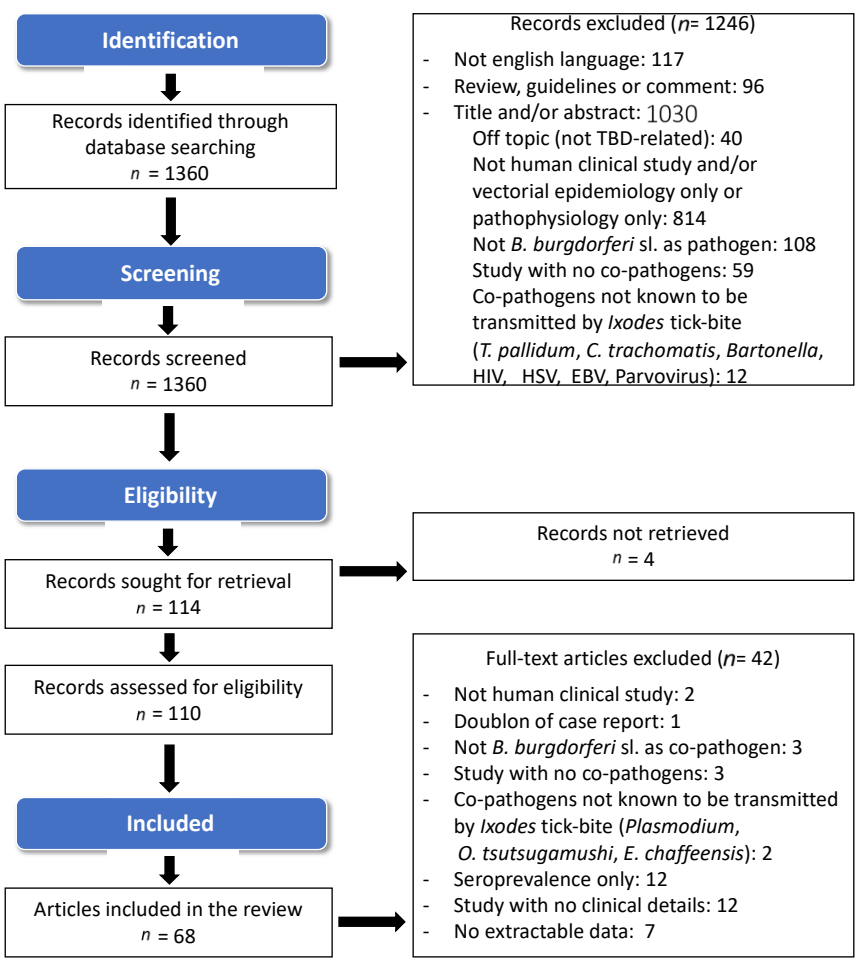

Figure 1. Flow chart of article selection for the review.

A total of 68 articles were included in this systematic review encompassing 28 case reports $(41.2 \%), 18$ prospective studies $(26.5 \%), 17$ retrospective studies $(25 \%)$, and 5 case 
series $(7.4 \%)$. Reports hailed mostly from Europe $(n=32-47.1 \%)$ and from the United States $(n=31-45.6 \%)$, and the remaining reports were from Asia $(n=5-7.3 \%)$. The total number of patients explored for co-infections in these studies was $n=5368$.

These 68 articles found 655 patients with a potential co-infection between B. burgdorferi s.1. and another Ixodes-borne microorganism. A co-infection caused by three microorganisms (including B. burgdorferi s.l.) was reported in 15 patients (2.3\% of the co-infection cases). On these patients, five patients had a triple acute active infection [11]: EM was observed with a proven HGA and TBE. Two more patients were found to have a triple active infection but did not meet the criteria of a confirmed infection [12,13]. For four patients, diagnosis of one of the three infections did not meet the clinical criteria [14,15]. For the other patients, diagnosis of at least one infection was made by serology.

\subsection{Frequency of Co-Infections}

Analysis of cohort studies allowed estimation of the frequency of alleged human coinfections. The median frequency of co-infection was 4\% (IIQ: 2.1-10.5\%) but varied greatly according to the explored cohort. Interestingly, frequency of coinfection was elevated for patients with a rare TBD, such as TBE (although this includes patients with proven infection and seropositivity for B. burgdorferi s.1.). Table 1 shows the detailed results.

Table 1. Frequency of co-infection according to the explored cohort (Tick Borne Encephalitis (TBE); Human Granulocytic Anaplasmosis (HGA); Borrelia miyamotoi disease (BMD)).

\begin{tabular}{|c|c|c|c|c|}
\hline Type of Cohort & Geographical Area & $\begin{array}{c}\text { No of } \\
\text { Patients Explored }\end{array}$ & $\begin{array}{l}\text { Frequency of } \\
\text { Co-Infection }\end{array}$ & References \\
\hline Tick bitten people & Europe & 495 & $1.0 \%$ & [16-19] \\
\hline Patients with LB suspicion & Europe & 214 & $0.9 \%$ & [20] \\
\hline Patient with LB & Europe & 24 & $4.2 \%$ & [21] \\
\hline Patients with EM & Europe \& US & 1309 & $5.9 \%$ & {$[10,22-30]$} \\
\hline Neuroborreliosis suspicions & Europe & 1333 & $2.7 \%$ & [31-35] \\
\hline Lyme arthritis suspicions & Europe & 146 & $0.7 \%$ & [36] \\
\hline TBE patients & Europe & 805 & $41.6 \%$ & {$[14,37,38]$} \\
\hline $\begin{array}{l}\text { Patients with post-tick } \\
\text { bite fever }\end{array}$ & Europe \& US \& China & 416 & $4.3 \%$ & [39-42] \\
\hline Patients with Babesiosis & US & 41 & $22.0 \%$ & [32] \\
\hline Patients with BMD & US & 51 & $11.7 \%$ & [15] \\
\hline $\begin{array}{l}\text { Patients with HGA or } \\
\text { HGA suspicion }\end{array}$ & US \& Europe & 496 & $9.7 \%$ & {$[9,11,43,44]$} \\
\hline
\end{tabular}

\subsection{Clinical Picture of LB Observed in Patients Deemed Co-Infected}

Lyme borreliosis diagnosis most frequently relied on nonspecific LB symptoms, i.e., a flu-like illness, associated with a positive serology or a whole blood positive PCR in $315 / 655$ cases $(48.1 \%)$.

Clinical picture of EM including six multiple EM (273/655 cases), followed by neuroborreliosis (93/655 cases) and Lyme arthritis (7/655 cases), were then reported. After article reviewing, the diagnosis met the criteria of a confirmed infection for $94.6 \%$ of the EM cases, $77.4 \%$ of the neuroborreliosis cases, and for $57.1 \%$ of the Lyme arthritis cases. Figure 2 shows detailed clinical pictures and their level of imputability. 


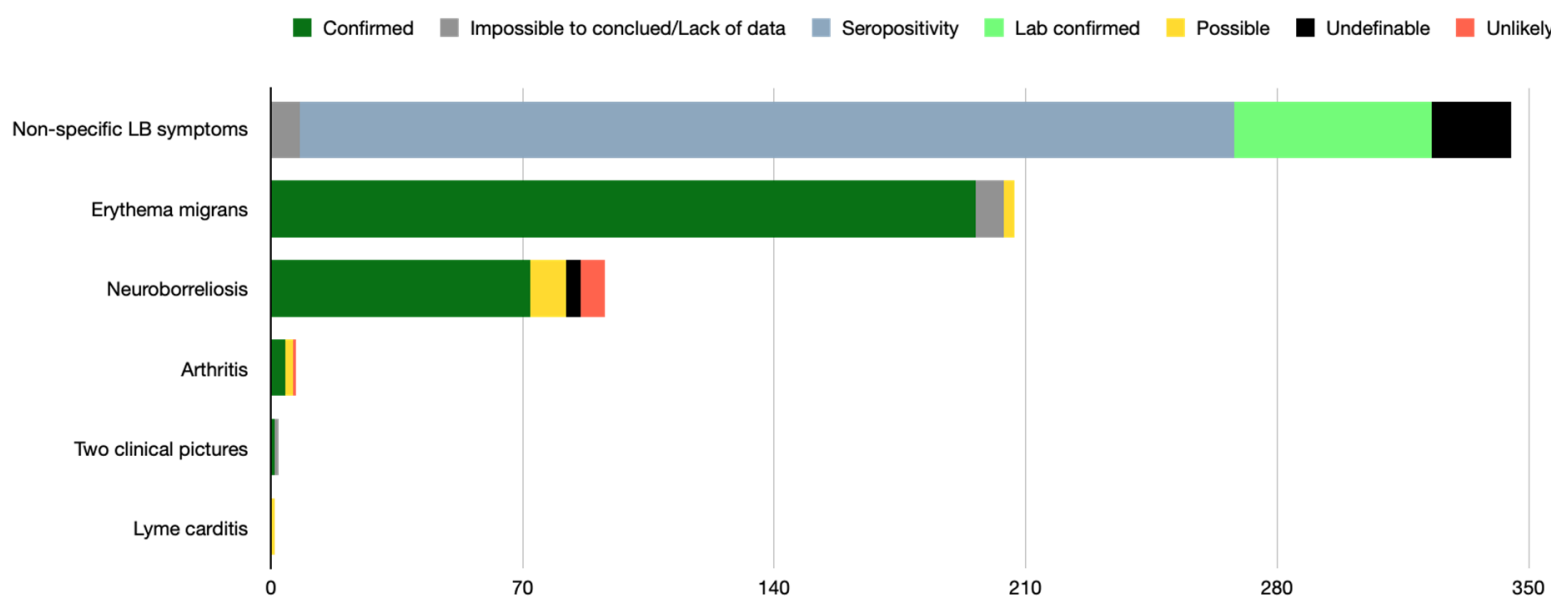

Figure 2. Clinical picture of Lyme borreliosis and their level of imputability (655 patients).

\subsection{TBMs Associated with B. burgdorferi s.l.}

The TBEv was the most frequent co-infection agent found in 378 patients and was evidenced in Europe only. In $96.6 \%$ of the cases, the diagnosis of TBE corresponded to the confirmed case definition according to the European Union guidelines [45]. A. phagocytophilum was found in 197 patients, reaching the confirmed case definition in $49.2 \%$ of the cases. For A. phagocytophilum, cases hailed from both the US and Europe. Reports of co-infection by Babesia spp. hailed almost exclusively from the US. In Europe, two cases of B. divergens positive PCR on blood without noticeable babesiosis symptoms were found [10,21]. The European clinical cases of Babesiosis due to B. microti corresponded to imported cases from the US, except for one autochthonous case in Switzerland [46]. Figure 3 presents the co-infection agents found with the level of imputability.

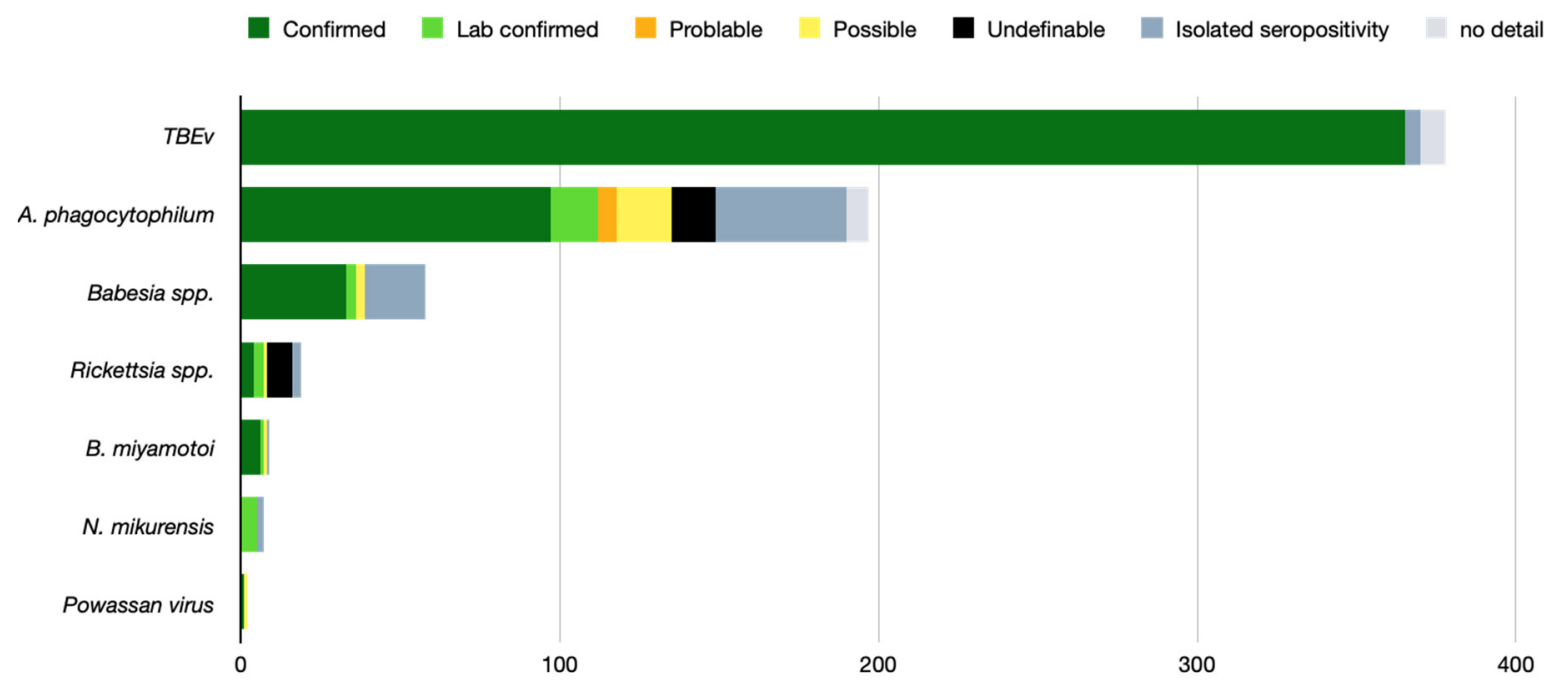

Figure 3. Co-infection agents found and their level of imputability (655 patients).

\subsection{Association between LB Clinical Presentation and Its Co-Pathogens}

The most common putative association found was TBEv and B. burgdorferi s.l. in 273 patients $(41.3 \%)$. In this situation, B. burgdorferi s.l. infection was evidenced on an isolated seropositivity (240 patients) or propped by PCR or seroconversion (33 patients). EM with $A$. phagocytophilum infection was the second most frequently observed association ( $n=148$ patients). Diagnosis of HGA met the criteria of a confirmed infection in 68/148 cases, a possible infection in 16/148 cases, and a probable infection in 4/148 cases. Asymptomatic A. phagocytophilum infection was found by PCR in 14/148, and the co-occurrence of an 
erythema migrans and an isolated $A$. phagocytophilum positive serology was found in $32 / 148$ cases.

Neuroborreliosis and TBEv co-infection was the third most common pattern observed with 77 cases reported. The diagnosis was confirmed in 62/77 cases (80\%) for both TBE and neuroborreliosis, which made this association the one with the highest rate of confirmation of two active infections. Generally, co-disease resulting from the concomitant infection of both B. burgdorferi s.l. and another TBM was observed in only 199/655 patients. It was confirmed for both agents in only 157/655 (24\%) patients. It corresponded to two precise situations: EM associated with another Ixodes borne microorganism causing post tick-bite fever, and neuroborreliosis plus a virus presenting neurotropism (i.e., TBEv or Powassan virus). Table 2 shows detailed association between LB clinical pictures and other TBMs reaching the confirmed definition cases.

Table 2. Detailed association between confirmed LB and confirmed disease caused by other TBM(s) (Tick Borne Encephalitis virus (TBEv)).

\begin{tabular}{cccc}
\hline LB Clinical Picture & Co-Infection Agent & $\begin{array}{c}\text { No. } \\
\text { of Patients }\end{array}$ & Reference \\
\hline & A. phagocytophilum & 63 & {$[11,23,25,29,30,40,42,47-49]$} \\
TBEv & 15 & {$[48]$} \\
Erythema migrans & Babesia spp. & 8 & {$[23,27,50-52]$} \\
& A. phagocytophilum & 5 & {$[11]$} \\
& \& TBEv & 2 & {$[41]$} \\
& Rickettsia spp. & 1 & {$[15]$} \\
B. miyamotoi & TBEv & 62 & {$[33,35,37,38,53]$} \\
\hline \multirow{2}{*}{ Neuroborreliosis } & Powassan virus & 1 & {$[54]$} \\
\hline
\end{tabular}

\subsection{Impact of Co-Infection}

The impact of co-infection versus mono-infection was evoked in 38 studies, which represented a total of 458 patients. For 359 (78.4\%) of them, co-infection had no impact on the symptoms. It mainly corresponded to an isolated seropositivity for one or the other microorganisms. These patients were mainly included in the study by Velušček et al. [37], which provided $240 \mathrm{TBE}$ patients with a B. burgdorferi s.l. seropositivity.

Symptoms' addition was found in 104 patients (21.6\%) and corresponded to the cooccurrence of an EM and a HGA in 73 patients who had both EM and high fever and biological abnormalities potentially linked to HGA. The co-occurrence of TBE and EM was also found in 15 patients. Finally, co-occurrence of TBE and neuroborreliosis was found to be clinically distinct in six patients.

\subsection{Treatment}

Patient treatment was not reported in 18 reviewed studies representing 188 patients. A total of 109 patients did not receive any etiological treatment. The latter were almost exclusively from a single study on TBE by Velušček et al. [37], in which the diagnosis of active B. burgdorferi s.l. was not retained for all patients.

Due to its versatility, doxycycline was the most prescribed molecule in 31 studies, especially against $A$. phagocytophilum and B. burgdorferi s.l. For babesiosis suspicion, specific anti-Babesia treatment was administered. Beta-lactams were prescribed alone or with anti-Babesia drugs in 21 studies.

\subsection{Outcome}

Patient outcomes were reported in only 49 of 68 reviewed studies, representing 109 patients. Most of the patients $n=91(83.5 \%)$ improved after treatment, 13 of them had sequels after the treatment and 5 died. For the five patients with a fatal outcome, three had babesiosis, one HGA in the US, and one TBE. For the 13 patients with an incomplete resolution, 
7 had a TBE, 3 had babesiosis, 2 had an infection by the Powassan virus, and 1 had HGA. The sequels were mainly neurological in patients with TBEv and Powassan virus infection.

\section{Discussion}

This systematic review aimed at collect all the clinical cases of co-infections in the literature where at least one of the two suspected diseases was clinically relevant, corresponding to 655 patients. To our best knowledge, this study is the first systematic review of human co-infections by TBMs. This latter fills a data gap underlined by Henningsson et al. in 2021 [55].

However, the rarity of co-infections is not conducive to large-scale case-controlled studies. Hence, we decided to use non-restrictive inclusion criteria to have the most complete possible picture of published cases of co-infection between microorganisms known to be transmitted by ticks of the Ixodes genus. As a result, a great heterogeneity was observed in the included articles. Nevertheless, despite efforts to make the bibliographical search as exhaustive as possible, some relevant articles may not have been found. However, the PubMed query used for this systematic review has the best bibliographical silence/noise ratio (data not shown).

The polysemy of the term 'co-infection' made the studies hard to compare. Hence, the imputability level we attributed in this review made it possible to distinguish between co-infection and co-disease. Although we decided to include articles presenting clinical cases, most of them presented only one proven disease with indirect evidence of contact with another microorganism without having any corresponding symptoms associated with it. Interpretation of serology must distinguish between a positive result, indicating a resolved past contact, and an active infection. Thus, serology allows the diagnosis to be established in the presence of specific symptoms of a perfectly described disease [56]. Moreover, serological non-specific reactions can also lead to false diagnosis of co-infection. This was evidenced, for example, in the case of a patient with clinically active babesiosis who may be wrongly diagnosed as having co-infection with Lyme borreliosis if IgM against B. burgdorferi was also positive [57]. Indeed, the IgM isotype is often not specific enough of Lyme borreliosis and can cross-react in case of babesiosis or HGA [9,57]. In addition, a biological documentation of Lyme borreliosis co-infection only based on a positive serology without objective clinical manifestations does not achieve a sufficient level of diagnostic evidence considering the in vivo long-term persistence of anti-Borrelia antibodies [56].

In this review, a tick-borne disease resulting from a concomitant infection by two microorganisms was not the most frequent case. This was further complicated by the fact that for some situations there was an overlapping of the symptoms which did not allow to distinguish the pathogenicity of one or the other, or both microorganisms (co-infection by three microorganisms being extremely rare). For example, post-tick bite fever is a cardinal symptom of several infections by TBMs (N. mikurensis, A. phagocytophilum, Babesia spp., and TBEv); in the US, it can also be caused by a B. burgdorferi s.l. infection [58]. This explains why in case of flu like illness caused, for example, by Babesia spp. or A. phagocytophilum, seropositivity for B. burgdorferi s.l. was recognized as LB. This remains questionable, and in the framework of LB, flu like illness is usually associated with other symptoms more suggestive of LB. Hence, co-infection with TBMs should be suspected and investigated in specific situations: in case of non-optimal response to antibiotic treatment of Lyme borreliosis, or in cases of severe clinical presentation of Lyme borreliosis with high-grade fever, anaemia, thrombocytopenia, or leukopenia [59-62]. The situation is more complicated in the case of lymphocytic meningitis or central or peripheral neurological deficit in a tick-exposed patient living in an endemic area for TBEv and B. burgdorferi s.l.; The documentation should cover both micro-organisms [63]. However, caution is required in the interpretation of serological results, especially for Lyme borreliosis, for which the index of intrathecal synthesis of anti-B. burgdorferi s.l. antibodies and/or PCR in CSF will have a major place in the diagnosis confirmation. 
Several studies have shown that co-infection in tick vectors may even be associated with a selective advantage for both pathogens in the case of B. microti/B. burgdorferi $[64,65]$. The risk of a human being simultaneously infected with several microorganisms via a co-infected tick bite depends on the prevalence of pathogens in the ticks and in the animal reservoir in the area concerned, the duration of transmission of pathogens after the beginning of the blood meal, and the vector transmission efficiency. Based on experimental animal studies, the transmission time after the start of the blood meal is notably faster for tick-borne flaviviruses (minutes to a few hours) than for Rickettsiales (since $24 \mathrm{~h}$ ) or B. burgdorferi s.l. and Babesia microti ( $>24 \mathrm{~h}$ ) [66]. However, it is not possible for a proven human co-infection to know whether the subject was bitten by a single tick that transmitted several pathogens or whether he was bitten concomitantly by different ticks that transmitted different microorganisms.

As discussed before, the frequency of co-infection depends greatly on the definition used for that term and the cohort explored. Indeed, they are more frequent in patients with a proven TBD, which suggests exposure to ticks. After a tick bite, the risk of developing TBD is already relatively low [17], the probability of developing two TBDs is even lower. Interestingly, the frequency of co-infection is higher in patients with relatively rare TBDs (e.g., HGA and TBE). Nevertheless, our review, due to the heterogeneity of the studies, only allows an approximate description of the frequency of co-infections.

The impact of co-infection versus mono-infection was also challenging to evaluate. Indeed, there is no study comparing two homogenous groups of patients: one group co-infected, and another one with a single infection. On the one hand, our review did not reveal any clear synergy or antagonism between the different microorganisms in humans. On the other hand, it was shown that there was an addition of cutaneous and general or neurological symptoms and an addition of neurological symptoms. Although, in this last situation, an overlapping existed.

Evidence of potentiation between Babesia spp. and B. burgdorferi s.l. was demonstrated in animal models of infection. In $\mathrm{C} 3 \mathrm{H}$ mice, $B$. microti enhances the severity of Lyme arthritis by reducing $B$ and $T$ cell functions [67]. These data were also corroborated by several other reports on the synergistic effect of B. burgdorferi s.l. and B. microti [66]. Nevertheless, a decrease of $B$. microti parasitemia was also reported in B. burgdorferi s.l. co-infected mice in another animal model [68]. Transposition of these animal models to human data is not easy. In a pioneer study, an increased severity (number of symptoms) and duration of illness were reported in patients co-infected with Lyme disease and babesiosis, but without any real possibility of being able to conclude if the infections were concurrent or successive [69].

In a similar way, multiple experimental studies have confirmed that infection with A. phagocytophilum modulates host immunity and increases susceptibility to various secondary pathogens, including B. burgdorferi s.l. In a mice model of Lyme arthritis, coinfection promotes more severe Lyme arthritis compared with those in mice infected with B. burgdorferi alone [70]. In an in vitro study on human brain microvascular endothelial cells [71], authors have demonstrated that co-infection with B. burgdorferi s.l. reduced transendothelial electrical resistance, and enhanced or synergistically increased the matrix metalloproteases and pro-inflammatory cytokines production, which are known to affect vascular permeability and inflammatory responses.

TBEv is also known to alter the blood-brain barrier, which is associated with an increase of the pro-inflammatory cytokine/chemokine mRNA expression in the brain of $\mathrm{BALB} / \mathrm{c}$ and $\mathrm{C57Bl} / 6$ mice [72], which may explain the elevated frequency of co-disease case TBE/neuroborreliosis.

\section{Materials and Methods}

\subsection{Search Strategy and Selection Criteria}

To investigate the human clinical cases of co-infection by B. burgdorferi s.l. and one or several other TBM, a systematic review and analysis of publications found on the PubMed database were conducted following the PRISMA guidelines. The following search terms 
were used: ('lyme' [All Fields] OR ('ticks' [MeSH Terms] OR 'ticks' [All Fields] OR 'tick' [All Fields])) AND (('coinfection' [MeSH Terms] OR 'coinfection' [All Fields]) OR 'coinfection' [All Fields] OR 'concomitant infection' [All Fields] OR 'concurrent infection' [All Fields] OR 'double infection' [All Fields] OR 'dual infection' [All Fields] OR simultaneous [All Fields]), and without filter for the time period. The request was performed on 28 July 2021. Titles and abstract were independently reviewed by two independent readers that were experts in the field (PHB and ETR).

\subsection{Inclusion Criteria}

The following inclusion criteria had to be met: (i) articles written in English; (ii) original studies or case reports; (iii) human clinical study about tick-borne diseases; (iv) study including at least one or more case of human infection by exposure to B. burgdorferi s.l. and one other TBM potentially transmitted by Ixodes ticks and (v) at least one of the TBMs.

\subsection{Exclusion Criteria}

The following exclusion criteria were used: (i) studies published in languages other than English; (ii) studies lacking clinical data; (iii) studies on tick vectors; (iv) studies on animals; (v) seroprevalence studies; and (vi) review papers. Abstracts without full manuscript texts were also excluded.

\subsection{Studies' Analysis and Data Collection}

Potentially eligible articles were selected and screened using their title and abstract. The articles were included or not according to the inclusion or exclusion criteria. The final inclusion was done by analyzing the full texts of the included articles. A consensus between the two readers was used to resolve any disagreement. Information regarding the authors, location, study design, characteristics and size of the explored cohort, clinical picture(s) described, diagnostic tests used, treatment, outcome, data on severity, and specific results was extracted and entered into an Excel sheet.

In order to compare studies, the initial diagnosis made by the authors was reviewed, and an imputability scoring system was established using clinical data and microbiological documentation. The diagnostic levels of evidence were defined according to international guidelines and are presented in the additional Table S2. Similarly, photographs of dermatological lesions were reviewed by an expert dermatologist (C.L)

\section{Conclusions}

This systematic review provides the first and accurate picture of the co-infections between $B$. burgdorferi s.l. and other microorganisms transmitted by Ixodes spp. ticks. Most 'co-infected' patients of the medical literature corresponded to patients with a single disease resulting from an infection by a TBM associated with a seropositivity for another TBM. Co-diseases (i.e., clinical expression of two active infections) are rarer. Co-occurrence of tick-borne encephalitis and neuroborreliosis was the most frequent co-disease pattern reported, which could justify the search for both agents in the presence of a neurological picture that evokes either disease. Similarly, in patients with EM, the occurrence of high fever should be investigated also for anaplasmosis or another agent responsible for post-tick bite fever.

Although animal models and in vitro studies suggest that co-infection between two TBMs may increase disease severity, we were unable to observe any clear impact of co-infection on human disease course, except for the co-occurrence of peculiar symptoms (e.g., high fever and EM).

Finally, to the best of our knowledge, no study has ever been conducted whose design makes it possible to assess both the severity and the frequency of co-infection. 
Supplementary Materials: The following supporting information can be downloaded at: https: / / www.mdpi.com/article/10.3390/pathogens11030282/s1, Table S1: Studies included in the review; Table S2: Clinical case definitions used in this review.

Author Contributions: Conceptualization, P.H.B., E.T.-R. and B.J.; methodology, P.H.B. and E.T.-R.; writing-original draft preparation, P.H.B., C.L., B.J. and E.T.-R.; writing-review and editing, C.L. All authors have read and agreed to the published version of the manuscript.

Funding: This research received no external funding.

Institutional Review Board Statement: Not applicable.

Informed Consent Statement: Not applicable.

Data Availability Statement: Data is contained within the article and supporting files.

Conflicts of Interest: The authors declare no conflict of interest regarding this publication.

\section{References}

1. Dantas-Torres, F.; Chomel, B.B.; Otranto, D. Ticks and Tick-Borne Diseases: A One Health Perspective. Trends Parasitol. 2012, 28, 437-446. [CrossRef]

2. Keirans, J.E.; Needham, G.R.; Oliver, J.H., Jr. The Ixodes Ricinus Complex Worldwide: Diagnosis of the Species in the Complex, Hosts and Distribution. Acarol. IX 1999, 2, 341-347.

3. Moutailler, S.; Valiente Moro, C.; Vaumourin, E.; Michelet, L.; Tran, F.H.; Devillers, E.; Cosson, J.-F.; Gasqui, P.; Van, V.T.; Mavingui, P.; et al. Co-Infection of Ticks: The Rule Rather than the Exception. PLOS Negl. Trop. Dis. 2016, 10, e0004539. [CrossRef]

4. Ginsberg, H.S. Potential Effects of Mixed Infections in Ticks on Transmission Dynamics of Pathogens: Comparative Analysis of Published Records. Exp. Appl. Acarol. 2008, 46, 29-41. [CrossRef] [PubMed]

5. Bertola, M.; Montarsi, F.; Obber, F.; da Rold, G.; Carlin, S.; Toniolo, F.; Porcellato, E.; Falcaro, C.; Mondardini, V.; Ormelli, S.; et al. Occurrence and Identification of Ixodes Ricinus Borne Pathogens in Northeastern Italy. Pathogens 2021, 10, 1181. [CrossRef] [PubMed]

6. Moustafa, M.A.M.; Taylor, K.; Nakao, R.; Shimozuru, M.; Sashika, M.; Rosà, R.; Thu, M.J.; Rizzoli, A.; Tsubota, T. Dynamics, Co-Infections and Characteristics of Zoonotic Tick-Borne Pathogens in Hokkaido Small Mammals, Japan. Ticks Tick-Borne Dis. 2016, 7, 922-928. [CrossRef] [PubMed]

7. Egizi, A.; Roegner, V.; Faraji, A.; Healy, S.P.; Schulze, T.L.; Jordan, R.A. A Historical Snapshot of Ixodes Scapularis-Borne Pathogens in New Jersey Ticks Reflects a Changing Disease Landscape. Ticks Tick-Borne Dis. 2018, 9, 418-426. [CrossRef] [PubMed]

8. Rigaud, E.; Jaulhac, B.; Garcia-Bonnet, N.; Hunfeld, K.-P.; Femenia, F.; Huet, D.; Goulvestre, C.; Vaillant, V.; Deffontaines, G.; Abadia-Benoist, G. Seroprevalence of Seven Pathogens Transmitted by the Ixodes Ricinus Tick in Forestry Workers in France. Clin. Microbiol. Infect. 2016, 22, 735.e1-735.e9. [CrossRef]

9. Wormser, G.P.; Horowitz, H.W.; Nowakowski, J.; Mckenna, D.; Stephen Dumler, J.; Varde, S.; Schwartz, I.; Carbonaro, C.; Aguero-Rosenfeld, M. Positive Lyme Disease Serology in Patients With Clinical and Laboratory Evidence of Human Granulocytic Ehrlichiosis. Am. J. Clin. Pathol. 1997, 107, 142-147. [CrossRef]

10. Jahfari, S.; Hofhuis, A.; Fonville, M.; van der Giessen, J.; van Pelt, W.; Sprong, H. Molecular Detection of Tick-Borne Pathogens in Humans with Tick Bites and Erythema Migrans, in the Netherlands. PLoS Negl. Trop. Dis. 2016, 10, e0005042. [CrossRef]

11. Moniuszko-Malinowska, A.; Dunaj, J.; Andersson, M.O.; Chmielewski, T.; Czupryna, P.; Groth, M.; Grygorczuk, S.; Zajkowska, J.; Kondrusik, M.; Kruszewska, E.; et al. Anaplasmosis in Poland-Analysis of 120 Patients. Ticks Tick-Borne Dis. 2021, 12, 101763. [CrossRef]

12. Grant, L.; Mohamedy, I.; Loertscher, L. One Man, Three Tick-Borne Illnesses. BMJ Case Rep. 2021, 14, e241004. [CrossRef] [PubMed]

13. Khan, A.M.; Shahzad, S.R.; Ashraf, M.F.; Naseer, U. Powassan Virus Encephalitis, Severe Babesiosis and Lyme Carditis in a Single Patient. BMJ Case Rep. 2019, 12, e231645. [CrossRef] [PubMed]

14. Moniuszko, A.; Dunaj, J.; Swięcicka, I.; Zambrowski, G.; Chmielewska-Badora, J.; Zukiewicz-Sobczak, W.; Zajkowska, J.; Czupryna, P.; Kondrusik, M.; Grygorczuk, S.; et al. Co-Infections with Borrelia Species, Anaplasma Phagocytophilum and Babesia Spp. in Patients with Tick-Borne Encephalitis. Eur. J. Clin. Microbiol. Infect. Dis. Off. Publ. Eur. Soc. Clin. Microbiol. 2014, 33, 1835-1841. [CrossRef]

15. Molloy, P.J.; Telford, S.R.; Chowdri, H.R.; Lepore, T.J.; Gugliotta, J.L.; Weeks, K.E.; Hewins, M.E.; Goethert, H.K.; Berardi, V.P. Borrelia Miyamotoi Disease in the Northeastern United States: A Case Series. Ann. Intern. Med. 2015, 163, 91-98. [CrossRef]

16. Lindblom, A.; Wallménius, K.; Sjöwall, J.; Fryland, L.; Wilhelmsson, P.; Lindgren, P.-E.; Forsberg, P.; Nilsson, K. Prevalence of Rickettsia spp. in Ticks and Serological and Clinical Outcomes in Tick-Bitten Individuals in Sweden and on the Åland Islands. PLOS ONE 2016, 11, e0166653. [CrossRef] [PubMed]

17. Ocias, L.F.; Wilhelmsson, P.; Sjöwall, J.; Henningsson, A.J.; Nordberg, M.; Jørgensen, C.S.; Krogfelt, K.A.; Forsberg, P.; Lindgren, P.E. Emerging Tick-Borne Pathogens in the Nordic Countries: A Clinical and Laboratory Follow-up Study of High-Risk Tick-Bitten Individuals. Ticks Tick-Borne Dis. 2020, 11, 101303. [CrossRef] [PubMed] 
18. Beltrame, A.; Ruscio, M.; Arzese, A.; Rorato, G.; Negri, C.; Londero, A.; Crapis, M.; Scudeller, L.; Viale, P. Human Granulocytic Anaplasmosis in Northeastern Italy. Ann. N. Y. Acad. Sci. 2006, 1078, 106-109. [CrossRef]

19. Grankvist, A.; Sandelin, L.L.; Andersson, J.; Fryland, L.; Wilhelmsson, P.; Lindgren, P.-E.; Forsberg, P.; Wennerås, C. Infections with Candidatus Neoehrlichia Mikurensis and Cytokine Responses in 2 Persons Bitten by Ticks, Sweden. Emerg. Infect. Dis. 2015, 21, 1462-1465. [CrossRef]

20. Kalinova, Z.; Halanova, M.; Cislakova, L.; Sulinova, Z.; Jarcuska, P. Occurrence of IgG Antibodies to Anaplasma Phagocytophilum in Humans Suspected of Lyme Borreliosis in Eastern Slovakia. Ann. Agric. Environ. Med. AAEM 2009, 16, $285-288$.

21. Welc-Falęciak, R.; Hildebrandt, A.; Siński, E. Co-Infection with Borrelia Species and Other Tick-Borne Pathogens in Humans: Two Cases from Poland. Ann. Agric. Environ. Med. AAEM 2010, 17, 309-313. [PubMed]

22. Tijsse-Klasen, E.; Sprong, H.; Pandak, N. Co-Infection of Borrelia Burgdorferi Sensu Lato and Rickettsia Species in Ticks and in an Erythema Migrans Patient. Parasit. Vectors 2013, 6, 347. [CrossRef] [PubMed]

23. Steere, A.C.; McHugh, G.; Suarez, C.; Hoitt, J.; Damle, N.; Sikand, V.K. Prospective Study of Coinfection in Patients with Erythema Migrans. Clin. Infect. Dis. Off. Publ. Infect. Dis. Soc. Am. 2003, 36, 1078-1081. [CrossRef] [PubMed]

24. Ocias, L.F.; Dessau, R.B.; Jørgensen, C.S.; Krogfelt, K.A.; Ornstein, K. More than Just Borrelia? A Study of Co-Infection and Etiology in Erythema Migrans Patients from Southernmost Sweden. Infect. Dis. 2019, 51, 618-621. [CrossRef] [PubMed]

25. Hulínská, D.; Votýpka, J.; Vanousová, D.; Hercogová, J.; Hulínský, V.; Drevová, H.; Kurzová, Z.; Uherková, L. Identification of Anaplasma Phagocytophilum and Borrelia Burgdorferi Sensu Lato in Patients with Erythema Migrans. Folia Microbiol. 2009, 54, 246-256. [CrossRef]

26. Moniuszko-Malinowska, A.; Dunaj, J.; Andersson, M.O.; Czupryna, P.; Zajkowska, J.; Guziejko, K.; Garkowski, A.; Grygorczuk, S.; Kondrusik, M.; Pancewicz, S. Assessment of Anaplasma Phagocytophilum Presence in Early Lyme Borreliosis Manifested by Erythema Migrans Skin Lesions. Travel Med. Infect. Dis. 2020, 36, 101648. [CrossRef]

27. Wormser, G.P.; McKenna, D.; Scavarda, C.; Cooper, D.; El Khoury, M.Y.; Nowakowski, J.; Sudhindra, P.; Ladenheim, A.; Wang, G.; Karmen, C.L.; et al. Co-Infections in Persons with Early Lyme Disease, New York, USA. Emerg. Infect. Dis. 2019, 25, 748-752. [CrossRef]

28. Christova, I.S.; Dumler, J.S. Human Granulocytic Ehrlichiosis in Bulgaria. Am. J. Trop. Med. Hyg. 1999, 60, 58-61. [CrossRef]

29. Horowitz, H.W.; Aguero-Rosenfeld, M.E.; Holmgren, D.; McKenna, D.; Schwartz, I.; Cox, M.E.; Wormser, G.P. Lyme Disease and Human Granulocytic Anaplasmosis Coinfection: Impact of Case Definition on Coinfection Rates and Illness Severity. Clin. Infect. Dis. Off. Publ. Infect. Dis. Soc. Am. 2013, 56, 93-99. [CrossRef]

30. Welc-Falęciak, R.; Kowalec, M.; Zajkowska, J.; Pancewicz, S.A.; Siński, E. Clinical and Molecular Features of One Case of Human Infection with Anaplasma Phagocytophilum from Podlaskie Province in Eastern Poland. Ann. Agric. Environ. Med. AAEM 2015, 22, 414-417. [CrossRef]

31. Gyllemark, P.; Wilhelmsson, P.; Elm, C.; Hoornstra, D.; Hovius, J.W.; Johansson, M.; Tjernberg, I.; Lindgren, P.-E.; Henningsson, A.J.; Sjöwall, J. Are Other Tick-Borne Infections Overlooked in Patients Investigated for Lyme Neuroborreliosis? A Large Retrospective Study from South-Eastern Sweden. Ticks Tick-Borne Dis. 2021, 12, 101759. [CrossRef] [PubMed]

32. Benach, J.L.; Coleman, J.L.; Habicht, G.S.; MacDonald, A.; Grunwaldt, E.; Giron, J.A. Serological Evidence for Simultaneous Occurrences of Lyme Disease and Babesiosis. J. Infect. Dis. 1985, 152, 473-477. [CrossRef] [PubMed]

33. Cimperman, J.; Maraspin, V.; Lotric-Furlan, S.; Ruzić-Sabljić, E.; Avsic-Zupanc, T.; Picken, R.N.; Strle, F. Concomitant Infection with Tick-Borne Encephalitis Virus and Borrelia Burgdorferi Sensu Lato in Patients with Acute Meningitis or Meningoencephalitis. Infection 1998, 26, 160-164. [CrossRef] [PubMed]

34. Ocias, L.F.; Dessau, R.B.; Lebech, A.-M.; Jørgensen, C.S.; Petersen, R.F.; Krogfelt, K.A. Evidence of Rickettsiae in Danish Patients Tested for Lyme Neuroborreliosis: A Retrospective Study of Archival Samples. BMC Infect. Dis. 2018, 18, 325. [CrossRef]

35. Tomazic, J.; Ihan, A.; Strle, F.; Cimperman, J.; Stare, J.; Maticic, M.; Zakotnik, B. Immunological Differentiation between Tickborne Encephalitis with and without Concomitant Neuroborreliosis. Eur. J. Clin. Microbiol. Infect. Dis. Off. Publ. Eur. Soc. Clin. Microbiol. 1997, 16, 920-923. [CrossRef]

36. Krbková, L.; Homola, L.; Hlaváčová, A.; Mikolášek, P.; Bednářová, J.; Čermáková, Z. Assessment of Antibodies against Surface and Outer Membrane Proteins of Anaplasma Phagocytophilum in Lyme Borreliosis and Tick-Borne Encephalitis Paediatric Patients. Epidemiol. Infect. 2016, 144, 2597-2604. [CrossRef] [PubMed]

37. Velušček, M.; Blagus, R.; Cerar Kišek, T.; Ružić-Sabljić, E.; Avšič-Županc, T.; F Bajrović, F.; Stupica, D. Antibiotic Use and Long-Term Outcome in Patients with Tick-Borne Encephalitis and Co-Infection with Borrelia Burgdorferi Sensu Lato in Central Europe. A Retrospective Cohort Study. J. Clin. Med. 2019, 8, E1740. [CrossRef]

38. Lotric-Furlan, S.; Strle, F. Peripheral Facial Palsy in Patients with Tick-Borne Encephalitis. Clin. Microbiol. Infect. Off. Publ. Eur. Soc. Clin. Microbiol. Infect. Dis. 2012, 18, 1027-1032. [CrossRef]

39. Belongia, E.A.; Reed, K.D.; Mitchell, P.D.; Mueller-Rizner, N.; Vandermause, M.; Finkel, M.F.; Kazmierczak, J.J. Tickborne Infections as a Cause of Nonspecific Febrile Illness in Wisconsin. Clin. Infect. Dis. Off. Publ. Infect. Dis. Soc. Am. 2001, 32, 1434-1439. [CrossRef]

40. Dunaj, J.; Moniuszko-Malinowska, A.; Swiecicka, I.; Andersson, M.; Czupryna, P.; Rutkowski, K.; Zambrowski, G.; Zajkowska, J.; Grygorczuk, S.; Kondrusik, M.; et al. Tick-Borne Infections and Co-Infections in Patients with Non-Specific Symptoms in Poland. Adv. Med. Sci. 2018, 63, 167-172. [CrossRef] 
41. Liu, H.-B.; Wei, R.; Ni, X.-B.; Zheng, Y.-C.; Huo, Q.-B.; Jiang, B.-G.; Ma, L.; Jiang, R.-R.; Lv, J.; Liu, Y.-X.; et al. The Prevalence and Clinical Characteristics of Tick-Borne Diseases at One Sentinel Hospital in Northeastern China. Parasitology 2019, 146, 161-167. [CrossRef]

42. Bjöersdorff, A.; Wittesjö, B.; Berglund, J.; Massung, R.F.; Eliasson, I. Human Granulocytic Ehrlichiosis as a Common Cause of Tick-Associated Fever in Southeast Sweden: Report from a Prospective Clinical Study. Scand. J. Infect. Dis. 2002, 34, 187-191. [CrossRef]

43. Mitchell, P.D.; Reed, K.D.; Hofkes, J.M. Immunoserologic Evidence of Coinfection with Borrelia Burgdorferi, Babesia Microti, and Human Granulocytic Ehrlichia Species in Residents of Wisconsin and Minnesota. J. Clin. Microbiol. 1996, 34, 724-727. [CrossRef]

44. Belongia, E.A.; Reed, K.D.; Mitchell, P.D.; Chyou, P.-H.; Mueller-Rizner, N.; Finkel, M.F.; Schriefer, M.E. Clinical and Epidemiological Features of Early Lyme Disease and Human Granulocytic Ehrlichiosis in Wisconsin. Clin. Infect. Dis. 1999, 29, $1472-1477$. [CrossRef] [PubMed]

45. Taba, P.; Schmutzhard, E.; Forsberg, P.; Lutsar, I.; Ljøstad, U.; Mygland, Å.; Levchenko, I.; Strle, F.; Steiner, I. EAN Consensus Review on Prevention, Diagnosis and Management of Tick-Borne Encephalitis. Eur. J. Neurol. 2017, 24, 1214-e61. [CrossRef]

46. Meer-Scherrer, L.; Adelson, M.; Mordechai, E.; Lottaz, B.; Tilton, R. Babesia Microti Infection in Europe. Curr. Microbiol. 2004, 48, 435-437. [CrossRef] [PubMed]

47. Duffy, J.; Pittlekow, M.R.; Kolbert, C.P.; Rutledge, B.J.; Persing, D.H. Coinfection with Borrelia Burgdorferi and the Agent of Human Granulocytic Ehrlichiosis. Lancet 1997, 349, 399. [CrossRef]

48. Nadelman, R.B.; Horowitz, H.W.; Hsieh, T.; Wu, J.M.; Aguero-Rosenfeld, M.E.; Schwartz, I.; Nowakowski, J.; Varde, S.; Wormser, G.P. Simultaneous Human Granulocytic Ehrlichiosis and Lyme Borreliosis. N. Engl. J. Med. 1997, 337, 27-30. [CrossRef]

49. Hulinska, D.; Votypka, J.; Plch, J.; Vlcek, E.; Valesová, M.; Bojar, M.; Hulinsky, V.; Smetana, K. Molecular and Microscopical Evidence of Ehrlichia Spp. and Borrelia Burgdorferi Sensu Lato in Patients, Animals and Ticks in the Czech Republic. New Microbiol. 2002, 25, 437-448.

50. Hoversten, K.; Bartlett, M.A. Diagnosis of a Tick-Borne Coinfection in a Patient with Persistent Symptoms Following Treatment for Lyme Disease. BMJ Case Rep. 2018, 2018, bcr-2018-225342. [CrossRef]

51. Saetre, K.; Godhwani, N.; Maria, M.; Patel, D.; Wang, G.; Li, K.I.; Wormser, G.P.; Nolan, S.M. Congenital Babesiosis After Maternal Infection With Borrelia Burgdorferi and Babesia Microti. J. Pediatr. Infect. Dis. Soc. 2018, 7, e1-e5. [CrossRef]

52. Martínez-Balzano, C.; Hess, M.; Malhotra, A.; Lenox, R. Severe Babesiosis and Borrelia Burgdorferi Co-Infection. QJM Int. J. Med. 2015, 108, 141-143. [CrossRef]

53. Oksi, J.; Viljanen, M.K.; Kalimo, H.; Peltonen, R.; Marttila, R.; Salomaa, P.; Nikoskelainen, J.; Budka, H.; Halonen, P. Fatal Encephalitis Caused by Concomitant Infection with Tick-Borne Encephalitis Virus and Borrelia Burgdorferi. Clin. Infect. Dis. 1993, 16, 392-396. [CrossRef] [PubMed]

54. Henningsson, A.J.; Aase, A.; Bavelaar, H.; Flottorp, S.; Forsberg, P.; Kirkehei, I.; Lövmar, M.; Nilsson, K.; Nyman, D.; Ornstein, K.; et al. Laboratory Methods for Detection of Infectious Agents and Serological Response in Humans With Tick-Borne Infections: A Systematic Review of Evaluations Based on Clinical Patient Samples. Front. Public Health 2021, 9, 580102. [CrossRef]

55. Dumic, I.; Glomski, B.; Patel, J.; Nordin, T.; Nordstrom, C.W.; Sprecher, L.J.; Niendorf, E.; Singh, A.; Simeunovic, K.; Subramanian, A.; et al. "Double Trouble": Severe Meningoencephalitis Due to Borrelia Burgdorferi and Powassan Virus Co-Infection Successfully Treated with Intravenous Immunoglobulin. Am. J. Case Rep. 2021, 22, e929952. [CrossRef] [PubMed]

56. Dessau, R.B.; van Dam, A.P.; Fingerle, V.; Gray, J.; Hovius, J.W.; Hunfeld, K.-P.; Jaulhac, B.; Kahl, O.; Kristoferitsch, W.; Lindgren, P.-E.; et al. To Test or Not to Test? Laboratory Support for the Diagnosis of Lyme Borreliosis: A Position Paper of ESGBOR, the ESCMID Study Group for Lyme Borreliosis. Clin. Microbiol. Infect. 2018, 24, 118-124. [CrossRef] [PubMed]

57. Wormser, G.P. Documentation of a False Positive Lyme Disease Serologic Test in a Patient with Untreated Babesia Microti Infection Carries Implications for Accurately Determining the Frequency of Lyme Disease Coinfections. Diagn. Microbiol. Infect. Dis. 2021, 101, 115429. [CrossRef]

58. Strle, F.; Stanek, G. Clinical Manifestations and Diagnosis of Lyme Borreliosis. In Lyme Borreliosis: Biological and Clinical Aspects; Karger: Basel, Switzerland, 2009; pp. 51-110.

59. Lantos, P.M.; Rumbaugh, J.; Bockenstedt, L.K.; Falck-Ytter, Y.T.; Aguero-Rosenfeld, M.E.; Auwaerter, P.G.; Baldwin, K.; Bannuru, R.R.; Belani, K.K.; Bowie, W.R.; et al. Clinical Practice Guidelines by the Infectious Diseases Society of America (IDSA), American Academy of Neurology (AAN), and American College of Rheumatology (ACR): 2020 Guidelines for the Prevention, Diagnosis and Treatment of Lyme Disease. Clin. Infect. Dis. Off. Publ. Infect. Dis. Soc. Am. 2021, 72, e1-e48. [CrossRef]

60. Krause, P.J.; Auwaerter, P.G.; Bannuru, R.R.; Branda, J.A.; Falck-Ytter, Y.T.; Lantos, P.M.; Lavergne, V.; Meissner, H.C.; Osani, M.C.; Rips, J.G.; et al. Clinical Practice Guidelines by the Infectious Diseases Society of America (IDSA): 2020 Guideline on Diagnosis and Management of Babesiosis. Clin. Infect. Dis. Off. Publ. Infect. Dis. Soc. Am. 2021, 72, e49-e64. [CrossRef]

61. Biggs, H.M.; Behravesh, C.B.; Bradley, K.K.; Dahlgren, F.S.; Drexler, N.A.; Dumler, J.S.; Folk, S.M.; Kato, C.Y.; Lash, R.R.; Levin, M.L.; et al. Diagnosis and Management of Tickborne Rickettsial Diseases: Rocky Mountain Spotted Fever and Other Spotted Fever Group Rickettsioses, Ehrlichioses, and Anaplasmosis-United States. MMWR Recomm. Rep. Morb. Mortal. Wkly. Rep. Recomm. Rep. 2016, 65, 1-44. [CrossRef]

62. Wormser, G.P.; McKenna, D.; Nowakowski, J. Management Approaches for Suspected and Established Lyme Disease Used at the Lyme Disease Diagnostic Center. Wien. Klin. Wochenschr. 2018, 130, 463-467. [CrossRef] 
63. Logina, I.; Krumina, A.; Karelis, G.; Elsone, L.; Viksna, L.; Rozentale, B.; Donaghy, M. Clinical Features of Double Infection with Tick-Borne Encephalitis and Lyme Borreliosis Transmitted by Tick Bite. J. Neurol. Neurosurg. Psychiatry 2006, 77, 1350-1353. [CrossRef]

64. Lou, Y.; Liu, L.; Gao, D. Modeling Co-Infection of Ixodes Tick-Borne Pathogens. Math. Biosci. Eng. MBE 2017, 14, 1301-1316. [CrossRef] [PubMed]

65. Hersh, M.H.; Ostfeld, R.S.; McHenry, D.J.; Tibbetts, M.; Brunner, J.L.; Killilea, M.E.; LoGiudice, K.; Schmidt, K.A.; Keesing, F. Co-Infection of Blacklegged Ticks with Babesia Microti and Borrelia Burgdorferi Is Higher than Expected and Acquired from Small Mammal Hosts. PLoS ONE 2014, 9, e99348. [CrossRef] [PubMed]

66. Hermance, M.E.; Thangamani, S. Tick-Virus-Host Interactions at the Cutaneous Interface: The Nidus of Flavivirus Transmission. Viruses 2018, 10, 362. [CrossRef]

67. Djokic, V.; Akoolo, L.; Primus, S.; Schlachter, S.; Kelly, K.; Bhanot, P.; Parveen, N. Protozoan Parasite Babesia Microti Subverts Adaptive Immunity and Enhances Lyme Disease Severity. Front. Microbiol. 2019, 10, 1596. [CrossRef]

68. Bhanot, P.; Parveen, N. Investigating Disease Severity in an Animal Model of Concurrent Babesiosis and Lyme Disease. Int. J. Parasitol. 2019, 49, 145-151. [CrossRef] [PubMed]

69. Krause, P.J.; Telford, S.R.; Spielman, A.; Sikand, V.; Ryan, R.; Christianson, D.; Burke, G.; Brassard, P.; Pollack, R.; Peck, J.; et al. Concurrent Lyme Disease and Babesiosis. Evidence for Increased Severity and Duration of Illness. JAMA 1996, 275, 1657-1660. [CrossRef]

70. Thomas, V.; Anguita, J.; Barthold, S.W.; Fikrig, E. Coinfection with Borrelia Burgdorferi and the Agent of Human Granulocytic Ehrlichiosis Alters Murine Immune Responses, Pathogen Burden, and Severity of Lyme Arthritis. Infect. Immun. 2001, 69, 3359-3371. [CrossRef]

71. Grab, D.J.; Nyarko, E.; Barat, N.C.; Nikolskaia, O.V.; Dumler, J.S. Anaplasma Phagocytophilum-Borrelia Burgdorferi Coinfection Enhances Chemokine, Cytokine, and Matrix Metalloprotease Expression by Human Brain Microvascular Endothelial Cells. Clin. Vaccine Immunol. CVI 2007, 14, 1420-1424. [CrossRef]

72. Růžek, D.; Salát, J.; Singh, S.K.; Kopecký, J. Breakdown of the Blood-Brain Barrier during Tick-Borne Encephalitis in Mice Is Not Dependent on CD8+ T-Cells. PLoS ONE 2011, 6, e20472. [CrossRef] 